\title{
Intellectual property and wildlife in china
}

\section{Opinion}

Wildlife refers to animals or plants that grow and breed in the wild. The international definition of wildlife is all kinds of animals or plants living in the natural environment without artificial rearing. In the academic field, wildlife is generally defined as: all kinds of animals or plants exist in natural free state or from natural free state, though they have been domesticated for a short time, but have not evolved. There are special wildlife protection regulations in China. Law of the People's Republic of China on the Protection of Wildlife is formulated for the purpose of protecting and saving the species of wildlife which are rare or near extinction, protecting, developing and rationally utilizing wildlife resources and maintaining ecological balances. Regulations for the implementation of the protection of aquatic wildlife in People's Republic of China was approval by the State Council in September 17, 1993; The Ministry of agriculture was released it in October 5, 1993; The State Council announced the first revision in January 8, 2011, The State Council announced the second revision in December 7, 2013. Regulations on the protection of wild plants in People's Republic of China is formulated for the purpose of protecting, developing and rationally utilizing wild plant resources, protecting biological diversity and maintaining ecological balance. Regulations of the People's Republic of China for the Implementation of the Protection of Terrestrial Wildlife was approval by the State Council in February 12, 1992; The Ministry of forestry was released it in March 1, 1992; The State Council announced the first revision in January 8, 2011; The State Council announced the second revision in February 6, 2016. The State Forestry Administration public the drafted special management method for the protection of terrestrial wildlife and products in People's Republic of China in October 31, $2016 .^{1}$

What is the implementation of wildlife management and protection in China? At present, there are 2740 natural reserves in China, with a total area of 1 million 470 thousand square kilometers, accounting for about $14.83 \%$ of the land area. Over the past 60 years, bio-diversity protection has accounted for more than 1/10 of China's natural reserves. In August 2015, the People's Republic of China Forestry Bureau issued a notice to further strengthen the management of the ivory and its products. The elephant is an endangered species of high international concern. Correctly handling the relationship between protection and ivory rational utilization is very important for maintaining correctly handling the relationship between protection and ivory rational utilization is very important for maintaining the traditional process of ivory carving, the inheritance and sustainable development of the national intangible cultural heritage of the traditional process of national intangible cultural heritage on ivory carving. Laojun Mountain national is located in Sichuan province Yibin City Pingshan County. The total area is 3500 hectares; the highest altitude is 2008.7 meters. This reserve is the first national nature reserve in China and even the world, which is mainly protected by Pheasant and other birds of the Sichuan mountain Partridge. The area of the protected area is only $2 \%$ of the total area of China's habitat, but the amount is about $20 \%$ of all the population, and there are 300 partridge. Guangxi Chongzuo white headed langur National Nature
Volume 3 Issue 2 - 2018

\author{
Jessee(Shi) Zhang \\ Law Master of China University of Political Science, \\ China
}

Correspondence: Jessee(Shi) Zhang, Engineering Master of Shenyang Agricultural University, Law Master of China University of Political Science, Xincheng 4 road, Beiguan Housing 8-5-203, Liaoning province, Funshun City, China, Tel +0 8601013811646350 ,

Email jessee_zhang@163.com

Received: February 05, 20I8| Published: March 0I, 2018

Reserve is located in the territory of Guangxi in the southwest of China in Jiangzhou District of Chongzuo city and Fusui County, about 75 kilometers east-west, about 48 kilometers wide north-south, a total area of 25578 hectares, of which the core area is 10093.3 hectares, accounting for $39.46 \%$, the buffer area is 6950.7 hectares, accounting for $27.17 \%$. Experimentation area is an area of 8534 hectares, accounting for $33.37 \%$. The main target for the protection are white headed leaf monkey, monkey and other wild animal and the survival of the Karst mountain forest ecosystem. Ar Horqin Banner Gourgues Taihan wula national nature reserve is located in south of Daxingan, and north of Ar Horqin Banner, a total area of 106284 hectares. Red deer, roe deer, lynx, great bustard, black stork, black grouse, wild boar and other wild animal has become a frequent visitor here although wildlife is protected by law; wild animal related products are still a lot. For example, fur clothes and bags and so on. What are the intellectual property rights related to wildlife? The US animal organization submitted a lawsuit to the court about a British wildlife photography company and a USA publishing company has violated the "intellectual property" of a macaque. This is the beginning of the topic of wildlife and intellectual property. Not only wildlife should be protected by law, but wildlife related intellectual property rights are also protected by law. The copyright of wild animals refers to the photos, films, videos of wildlife. A group of lifelike and rare animal "specimens" attracted many visitors in the third Northeast Asia Investment and Trade Fair. But this is not a specimen made from a real rare animal fur, but an imitation. These patent certificates "stored simulation rare wild animal forms and fur", the inner mold is unsaturated polyester resin, the outer cover of horses, cattle and other animal fur, all pure handmade. It can be seen that the process of making the specimen of wildlife or the product can be patented and protected by intellectual property. ${ }^{2}$ There are also many intellectual property rights about the trademarks or signs of wildlife. Some businesses making wildlife products use wildlife to apply for trademarks. ${ }^{3}$

\section{Conclusion}

The laws related to intellectual property rights in China do not make special provisions for wildlife, and have not been reflected in the revised copyright law and patent law. The intellectual property related 
to wildlife has not attracted the attention of the legal community. The protection of intellectual property rights of wildlife is good and bad. The topic of intellectual property rights of wildlife should arouse the attention of the Chinese legal community. How to protect wildlife related intellectual property rights is also beneficial to the protection of wildlife. ${ }^{4}$

\section{Acknowledgment}

None.

\section{Conflict of interest}

Author declares there is no conflict of interest.

\section{References}

1. GU case G Department $\mathrm{C}$ baked b love head State protected area. China Wildlife Conservation Association. China;2015.

2. Nearly $15 \%$ of our country's nature reserve contains most of the major relics. China Wildlife Conservation Association. China;2015.

3. Higah Geostai National Nature Reserve becomes the home of wildlife. China Wildlife Conservation Association. China;2015.

4. Animal Protection Organization: Infringe on monkey intellectual property. China;2015. 